\title{
Skin Grafts Associated with Platelet Rich Plasma and Surgical Sponge-Literature Review
}

\author{
Josiane M. Pazzini ${ }^{1}$, Eduardo L. Serafim ${ }^{1}$, Ricardo R. A. Uscategui ${ }^{1}$, Vivian T. Almeida ${ }^{1}$, Carlos A. C. Oliva ${ }^{1}$, \\ Fátima Gärtner, ${ }^{2,3}$, Irina Amorim ${ }^{2,3}$, Fátima Faria ${ }^{2,3}$, Alexandra Rêma ${ }^{2,3}$, Nazilton P. R. Filho ${ }^{1}$, \\ Marília G. P. A. Ferreira ${ }^{1}$, Ana C. Silva ${ }^{1}$, Rafael R. Huppes ${ }^{4}$, Paola Castro Moraes ${ }^{1}$, João A. Oliveira ${ }^{5}$ \\ \& Andrigo B. De Nardi ${ }^{1}$ \\ ${ }^{1}$ Department of Veterinary Surgery, Faculty of Agricultural and Veterinary Sciences, Universidade Estadual \\ Paulista, Jaboticabal, SP, Brazil \\ ${ }^{2}$ Department of Veterinary Pathology, University of Porto, Porto, Portugal \\ ${ }^{3}$ Abel Salazar Biomedical Sciences Institute, University of Porto, Porto, Portugal \\ ${ }^{4}$ Department of Veterinary Surgery, Unicesumar, Maringá, PR, Brazil \\ ${ }^{5}$ Department of Statistics, Faculty of Agricultural and Veterinary Sciences, Universidade Estadual Paulista, \\ Jaboticabal, SP, Brazil \\ Correspondence: Josiane M. Pazzini, Department of Veterinary Surgery, Faculty of Agricultural and Veterinary \\ Sciences, Universidade Estadual Paulista, Jaboticabal, SP, Brazil. Tel: 55-169-9151-5157. E-mail: \\ josipazzini@hotmail.com
}

Received: January 5, $2017 \quad$ Accepted: February 13, $2017 \quad$ Online Published: March 15, 2017

doi:10.5539/jas.v9n4p51 URL: https://doi.org/10.5539/jas.v9n4p51

Research with the support of Capes and PDSE-Doctoral Program Sandwich, and Cnpq (Process number: 147728/2016-9).

\begin{abstract}
Skin graft is one of the techniques used to reconstruct surgical wounds. The graft is composed of epidermal and dermal segments that are completely removed from the donor region and transferred to the recipient bed. After its implantation it's recommended to make compressive dressing in the receiver bed. Since the grafts do not have a vascular pedicle, it's important to make the compressive dressing to improve graft contact with the wound and allow adequate angiogenesis. The compressive dressing is made with a sponge or foam, which offers adequate protection and reduces the discomfort of the patient in the postoperative period. The use of platelet-rich plasma (PRP) is the objective of several studies associated with the reduction of postoperative surgical complications, especially necrosis. This product is a result of the centrifugation of the patient's blood that promotes the separation of its constituents and allows the extraction of plasma with higher concentration of platelets. PRP improves the tissue healing process by releasing biological mediators and growth factors at the site of application. Researches on platelet-rich plasma used in reconstructive surgery are important because this product has therapeutic characteristics to promote healing. When it's used in skin grafts, platelet-rich plasma is able to improve graft integration in the recipient bed, and reduce necrosis after the surgical procedure. The use of postoperative surgical sponges associated with platelet-rich plasma is indicated to improve the healing of the graft and to avoid its displacement of the recipient bed.
\end{abstract}

Keywords: reconstructive surgery, skins grafts, PRP, compressive dressing

\section{Introduction}

Reconstructive surgeries are formed by various techniques which can be used to repair large defects with loss of continuity of the integument or lack of skin elasticity, that compromise wound healing. Thus, in these cases, the use of skin grafts or flaps are options for treatments (Pavletic, 2010).

Flaps consisted of a tissue segment partially removed from its original location and dislocated to another which will overlie the defect. The greatest advantage of using skin flaps is the immediate closure of the affected region, 
as well as reducing the tissue healing time, which gives the patient not only better functional but also aesthetic results (Hedlund, 2005).

Therefore, grafts are epidermis and dermis segment that are completely removed from the donor site and transferred to the receiving region (Hedlund, 2008; William et al., 2013). However, being devoid of an artery and vein in its constitution are very affected by necrosis and ischemia after being implanted in the receiving region (Pope, 1996).

According to Adams et al. (2005), vascularization of the flaps and grafts is necessary, and much have discussed about the proportions of length and width of the flaps are fundamentally determine their viability, as when it is extensive, occurs vascular compromise and distal regions are left without blood supply, causing necrosis in distal margins. The grafts are devoid of artery and vein in its constitution, so are affected by necrosis after implanted in the recipient region (Tobias, 2011). After faced with these problems, many authors have reported the use of substances to improve healing, by stimulating angiogenesis, which was boosted by the use of platelet-rich plasma (PRP) in surgical wounds (Vendramin et al., 2010; Pazzini et al., 2016a).

The preparation of grafts is done only with the presence of healthy granulation tissue into the receiving region; however, this condition makes the lengthy procedure being conducted in three steps: first carrying out disinfection of the wound, next after following it wait for the presence of tissue granulation, and finally the surgical correction (Pazzini et al., 2015). As soon as the surgery is done, the dressing employment is essential, knowing that grafts are devoid of vascular pedicle, thus using compressive dressings can optimize the contact between the graft and the wound and then it allows proper angiogenesis (Pavletic, 2010).

Curatives also reduce the possibility of graft dislocations, as well as minimize the presence of hematomas and seromas, events which usually leads to loss of viability of the graft and subsequently death (Pazzini et al., 2015). Moreover, the more compressive dressings are used Tie over (Fossum, 2007), which consists of suture material on the wound, and can be done with cotton, surgical sponges and foams. The idea of surgical sponges or foam is practical, by evenly distributing pressure on the wound (Zanini, 2004), and to promote healing and integration of the graft to the receiving region.

The aim of this study is to make a review of the main features and answer questions about platelet-rich plasma, skin grafts and surgical sponges.

\section{Reconstructive Surgery}

Wound large areas caused by trauma, congenital abnormalities, and tumors that result in loss of viability of tissues and lead to healing by secondary intention, are cases that need to use reconstructive surgical techniques (Castro et al., 2015). However, the procedure success will depend on upon the extent of an injury and the amount of how involved structures (Slatter, 2007). Reconstructive surgery should be planned by considering the wound location, tissue elasticity available blood supply and quality of wound local (Fossum, 2007).

Throughout the execution of reconstructive surgery, it is essential to preserve the microcirculation of the skin to maintain its viability (Mota et al., 2012). However, when microcirculation is not conserved, due to inadequate surgical manipulation, you can begin a process of ischemia and subsequently lead to local necrosis of the surgical procedure involving the entire region (Slatter, 2007; Amsellem, 2011) (Figure 1). 


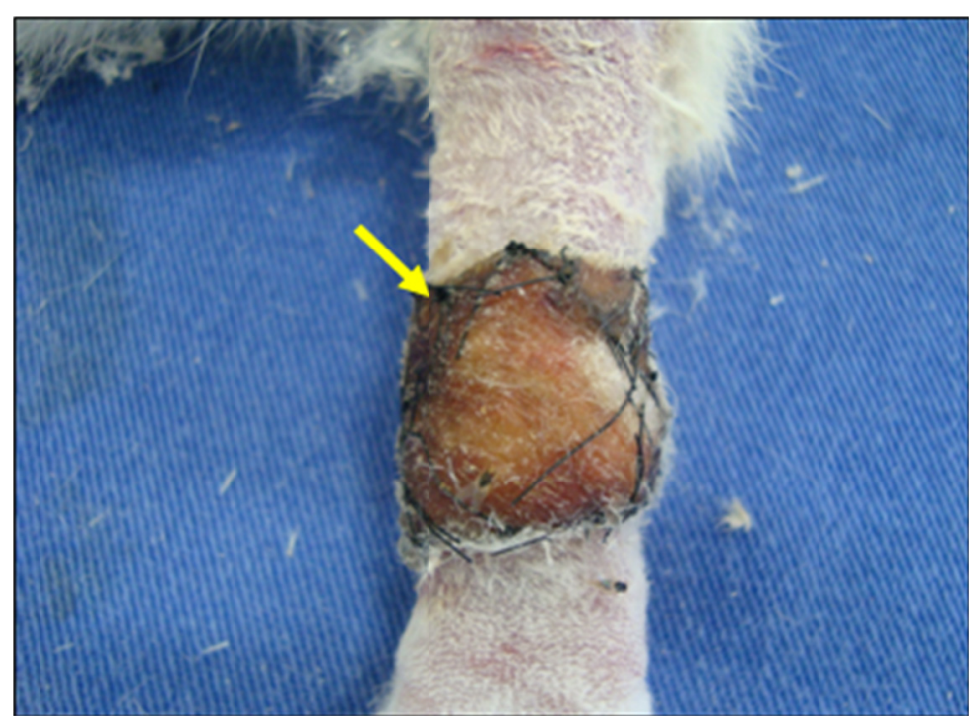

Figure 1. Images of the lesion in the left forelimb in carpal region of rabbits (Oryctolagus cuniculus) showing the necrosis macroscopic variables (Arrow) with 15 days that were submitted to the reconstructive surgery procedure at the Veterinary Hospital Faculty of Agricultural and Veterinary Sciences (FCAV) of UNESP, Jaboticabal Campus, 2015

According to Pavletic (2007), wounds that have difficulty in healing by primary sutures should be treated with reconstructive techniques which can be either adopted flaps or skin grafts for correction. The use of these techniques is a useful therapeutic alternative to reconstructing injuries resulting from trauma, removing tumors, or ischemia.

\section{Skin Grafts}

A skin graft is useful to reconstruct surgical wounds since preserved the principles of vascularization, antisepsis, and hemostasis (Zanini, 2004). A skin graft is a segment the epidermis and dermis that are completely removed from the donating region and transferred to the receiving area (Hedlund, 2008).

The grafts receive their nomenclature as their origins, such as autograft, isografts, allografts, and xenografts. In the autograft donor and recipient are obtained from the same patient. Isografts are obtained from donors of the same species and genetically identical to the receiver as monozygotic twins. Already allografts are obtained from donors of the same species, but genetically different. And xenografts are derived from animals of different species (Pavletic, 2010).

Grafts are classified according to their thickness, and it may be complete or partial (William et al., 2013). Full thickness consists of the epidermis and dermis full and partial thickness composed of epidermis and dermis variable layers (Pazzini et al., 2015).

The advantage of partial-thickness grafts is associated with viability greater than the total thickness. However, significant disadvantages are more essential fragility, lack of hair growth in some cases; in addition to collecting require specific material (Fossum, 2007). For these reasons, use is preferably the full thickness grafts (Corr, 2009).

According to Fowler (2006), full-thickness grafts have some advantages when compared with partial thickness, have components responsible for similar cicatrization of the healthy skin, promoting hair growth and being able to withstand injury as well as to normal skin. Also provide good color and texture to the receiving region, and are characterized by having minimal shrinkage of the wound, and adnexal structures remain intact dermis (Ratner 1998). Different from the partial grafts, full thickness does not require specialized equipment for collect, addition success rate is as good as that obtained with partial grafts (Pazzini et al., 2015).

Application of grafts is limited in veterinary medicine, by being necessary to await the formation of the previous granulation tissue before surgery, making it impossible in some cases their use (Pavletic, 2007). Therefore use components that stimulate angiogenesis and promote healing are options to allow use graft surgical routine (Pazzini et al., 2016a). 


\section{Types of Grafts}

Skin Grafts are produced in lateral chest wall and areas containing abundant skin (Fossum, 2007). Skin grafts are divided into full and partial thickness. Full thickness grafts consist of dermis and complete epidermis. And partial thickness grafts consist of a dermis and a variable dermis layer (Pope, 1996). Full-thickness grafts are better than partial thickness grafts because they are more resistant to trauma. On healing, hair growth is similar to normal skin, and the grafting can be done with a scalpel only, and the grafts in partial thickness Are fragile, hair growth does not occur during healing, and for making this graft, special material is needed (Pope, 1996).

Layer grafts are used in places with free granulation tissue infection, but have disadvantages in the degree of expansion, by being less flexible and less adaptable (Pavletic, 1999). The grafts mesh have parallel incisions in the shape of slits, which promote drainage, flexibility, conformation and expanding (Hedlund, 2008). This type of graft has many advantages and can be expanded to close large defects, conform well to irregular surfaces, this occurs presence of the slits is better drainage of exudate, and for this purpose can be used in difficult areas to immobilize (Pazzini et al., 2015; Pope, 1996).

Such a graft can be made with particular device expansion or manually. Grafts mechanically processed into mesh are more expandables than those created manually because first expands into more than one direction, and second in only one direction, however, the therapeutic effect is similar and is manually accessible and inexpensive (Pazzini et al., 2015). It is known that cosmetic appearance is better when the slits are placed in parallel the skin tension lines (Pavletic, 2010; Fossum, 2007).

Graft survival is a widely discussed issue because of the lack of a vascular pedicle to perform its nutrition in the recipient bed, and healing can be compromised because of the absence of vessels (Hedlund, 2007).

After implanted the graft into the receiving region, the cicatrization begins with plasmatic imbibition phase, following inosculation, revascularization and finally contraction (Fossum, 2007).

Plasmatic imbibition phase happens approximately 24 hours after surgery, this period occurs the ischemia of the graft (Ratner, 1998), due to its removal from the donor area. Blood vessels have a spasm, and eliminate part of blood components by the edges of sectional overhead vessels, such as erythrocytes and leukocytes, and these accumulate between the graft and its receiving region (Pope, 1996).

Soon after the implantation of the graft in the receiving area, happens transudation of plasma, for the nutrition and to assist graft fixation. This phenomenon consists of the graft to adhere the mesh of fibrin, and fibrin filaments shrink for coating the wound (Pazzini et al., 2015). Fibroblasts, leukocytes, and phagocytes invade the fibrin mesh, converting it into the fibrous tissue between the graft and its receiving region (Pope, 1996). In this phase, there may be a presence of edema because of inadequate circulation to promote venous and lymphatic drainage. After reestablished drainage, a liquid is removed and happens regression the edema, normalizing aspect of the graft (Pazzini et al., 2015). According to Ratner (1998), this fibrin present in the graft is gradually replaced by granulation tissue, being able to promote permanent graft adherence to his local, favoring the process of revascularization.

Following in inosculation phase where it occurs the anastomosis of small capillaries which are between responsible for communicating the graft surface to the receiving region, this phenomenon happens within 24 hours after the surgery, and at that stage the fibrin mesh keeps the graft the fixed to his local, assisting as a support structure for the formation of vascular sprouts in receiving region graft (Pope, 1996). It is known that many vessels can contact and suffer anastomosis, but few that survive, so it is only possible to know if the surgery went well after the phase of revascularization (Pazzini et al., 2015).

In revascularization phase, the graft is still fragile and cyanotic, because it does not have real vessels. This step happens approximately five to seven days of surgery, and there is the formation of new blood vessels, which are responsible for the actual graft flow (Ratner, 1998). The neoformed capillaries have about 5 to $15 \mu \mathrm{m}$ in diameter, and by constant divisions of the arterioles they give rise to the venules (Konig et al., 2011). Besides blood vessels, they are also formed new lymphatics, which promote lymphatic drainage graft (Hedlund, 2008).

Finally, the last phase of healing of the grafts is the contraction which happens so late, and can last up to six months of surgery. In this phase myofibroblasts and contractile ptoteínas are responsible for the contraction of the graft in the receiving region. This moment some adverse cosmetic effects can occur, such as the presence of irregular scars and bad cosmetic aspects (Pazzini et al., 2015). 


\section{Skin Graft: Immobilization and Dressings}

Once the graft is done, the fixation of the pressure dressing on the receiving area is fundamental to the success of the surgical procedure. This dressing is necessary for large and thickness grafts. However, there are some situations where the pressure dressing is not recommended, as in infected wounds or located in areas that potentially produce a large amount of lymph, as an inguinal region (Vasconez, 1994).

It is known that the graft does not have vascular pedicle, and for this reason recommended compression bandage to optimize the contact of the graft to the wound and allow for adequate angiogenesis. In between three to five days begin communications with vascular arise transplanted skin, so the pressure dressing reduces a possibility of dislocations that affect this communication. Furthermore, they enable reduced occurrence of seroma and hematoma, events that frequently leads to loss of vitality and, consequently, to graft failure (Leffel, 1994).

According to Larson (1990), the appropriate pressure on the graft varies from 15 to $30 \mathrm{mmHg}$, so if the weight is not suitable may predispose fluid collections. However, excessive pressure can compress the capillaries and determine necrosis of the graft (Amsellem, 2011). Ideal compression is achieved with some materials such as surgical gauze, cotton, and sponge (Figura 2).

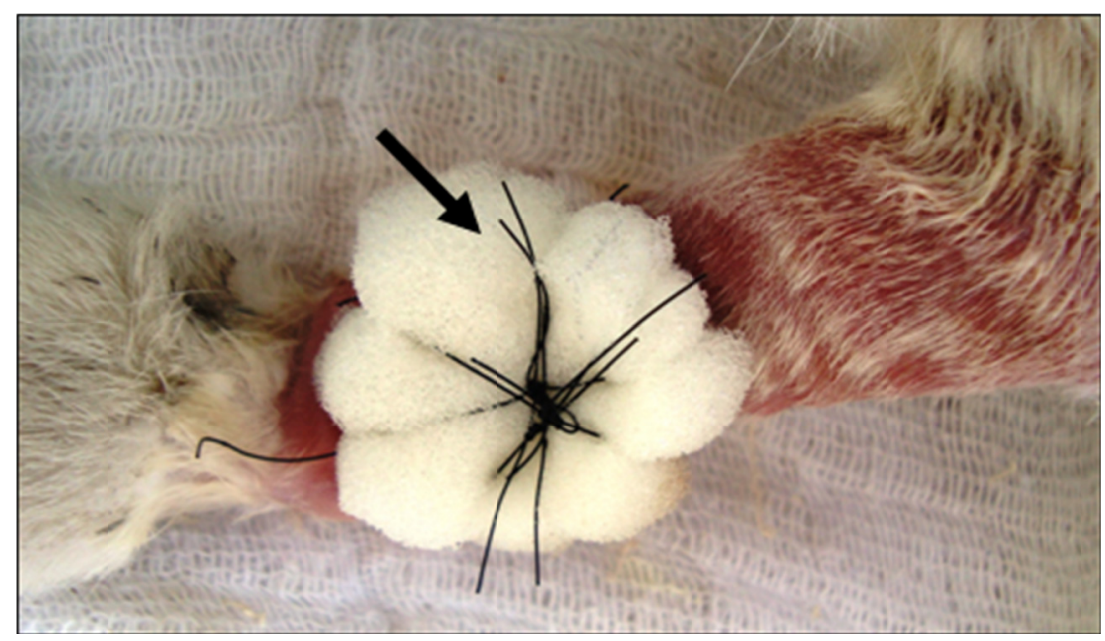

Figure 2. Images of the lesion in the left forelimb in carpal region of rabbits (Oryctolagus cuniculus) showing the pressure dressing used sponge (Arrow) with 15 days that were submitted to the reconstructive surgery procedure at the Veterinary Hospital Faculty of Agricultural and Veterinary Sciences (FCAV) of UNESP, Jaboticabal

Campus, 2015

The usual technique of pressure dressing is suture surgical gauze agglomerate on the graft, known as Tie over (Pavletic, 2010). This dressing is kept for a period which ranges from seven to fourteen days, since there are no signs of infection, hemorrhage, and loss of immobilization. Otherwise, the dressing should be removed, and the graft reevaluated (Hedlund, 2008).

However, other materials can be used as compressive dressings like gauze, cotton, plastic discs and wax molds (Vasconez, 1994). The idea of sponge or foam use appeared in 1929 (Blair et al., 1929), the authors of this discovery, better pressure on the graft was from the utilization of the sponge.

According to Zanini et al. (2004), to use the surgical sponge, should initially make their preparation, being done in two steps. First, highlight the brush sponge, being a simple process. Furthermore, by using scissors or a scalpel blade, it reduces the thickness of the sponge to $0.8 \mathrm{or} 1 \mathrm{~cm}$. It is important to leave a portion of about $0.5 \mathrm{~cm}$ around the edge of the graft. Before starting the placement of the dressing evaluates absence of bleeding and verify correct placement of the graft. The suture should exercise adequate tension to keep set the graft. The evaluation must be done in a period that can range from 24 to 72 hours to observe any surgical complication. The dressings and sutures are removed in seven days face and two weeks elsewhere.

The main advantages of using sponge are low cost, by offering adequate protection of the graft, easily performed a technique, formable into different shapes, have uniformly distributed pressure, easy removal, and provide a reduction of post-operative patient discomfort. When compared to post-operative care of the usual technique 
with gauze or cotton, sponge seems to be more practical for do not accede to the graft, but if this occurs in some case, it can remove it more quickly (Blair et al., 1929). In cases where there is a need to evaluate the graft, both as to the sponge removal replacement is easier than other techniques. The reduction of patient discomfort means that any bleedings occurring in post-operative likely to be completely absorbed by the sponge (Zanini et al., 2004).

The great benefit of reconstructive surgery is to allow the patient to return their normal routine more quickly and with satisfactory cosmetic results. In some cases, complications can occur, such as inadequate vascularization, graft handling and infection, and factors that predispose the occurrence of necrosis (Amsellem, 2011). In such cases, the graft will present inviability signals in about three to four days after surgery, with paler staining, which moves rapidly to black segment indicating necrosis (Richard, 1999). Thus, the neovascularization-related problems in surgical procedures are the focus of studies in various medical fields, especially in orthopedics and dentistry. Thus, the platelet-rich plasma (PRP) is the subject of several studies associated with complications in these areas.

This product, platelet rich plasma results from the patient's blood processing centrifuges which promote the separation of its constituents, and allows extraction from plasma with a higher concentration of platelets and is capable of potentializing the wound healing process through the release of biological mediators and growth factors at the application site (Pagliosa et al., 2007). It is believed that this product stimulates various processes involved in tissue recovery including mitosis, cell differentiation, chemotaxis and angiogenesis (Garcez et al., 2013).

\section{Platelet-Rich Plasma (PRP)}

According to Jain (1993), blood is a fluid tissue that circulates through the blood vessels carrying essential elements to the cells and receives the waste metabolites to take them in excretory organs. Blood contains three components being red blood cells, platelets, and leucocytes, which are dissolved in the liquid known as plasma (Reece et al., 2006).

PRP is obtained by the centrifugation of autologous blood, which results in increased concentration of platelets in a smaller volume of plasma (Pagliosa et al., 2007). Evidence of the effectiveness of its use is subject to many studies. However, researchers are seeking knowledge of the effectiveness of its biological effects when applied to soft tissue, bone, and skin (Anitua et al., 2007; Silva et al., 2011).

Production of the PRP at first was to reduce the presence of bleeding during surgical procedures; however, its use was propagated in various human healing modalities. In 1998 it was published a study reporting the success of the healing bone graft when combined with platelet-rich plasma (Marx et al., 1998; Albuquerque et al., 2008; Garcez et al., 2013). Thus, with this episode, the product started to be used in orthopedic surgery, cardiac, plastic, general, vascular, neurological, obstetric, gynecological and ophthalmic, to avoid complications and achieve success in the proceedings (Floryan et al., 2004).

Platelet rich plasma has a gelatinous consistency. In order to obtain the gel it is necessary to carry out the enrichment process. First, platelets go through an enrichment process in which one searches obtain greater numbers of platelets to activate at least 60 their biologically active substances. This activation is essential because of tissue repair processes, which are responsible for promoting chemotaxis, proliferation, cell differentiation, immune modulation, remodeling and microbial activity (Bolta, 2007; Vendramin et al., 2010). However for this process to happen in all its phases, it is important the participation of an agonist agent at the time of platelet activation (Jain, 1993).

Platelet activation is to modify the format of the projection of the platelets to release their inside contents (Reece et al., 2006). Inside the platelets there are three types of storage compartments that are $\alpha$ granule, dense and lissosomais, and most of the substances found are stored in $\alpha$ granule. The granules secrete biological mediators after platelet activation and the liberated elements are thrombin, thromboxane $\mathrm{A}^{2}$, adenosine diphosphate, thromboplastin, coagulation factors, calcium, serotonin, histamine, von Willebrand factor, fibrinogen, and catecholamines, being the growth factor a greater substance in the production of platelet rich plasma is (GF) (Bolta, 2007).

The growth factor production happens in several tissues and cells such as fibroblasts, macrophages, endothelial cells, osteoblasts, and leukocytes, salivary and lacrimal glands. However, in the platelet studies are the subject of most interest, because they are easy to obtain and incorporate other essential substances in the regeneration process and tissue repair (Santos, 2007). 
One of the growth factors and most abundant found in $\alpha$-platelet granules are growth factors derived from platelets (PDGF), and growth factor beta transformer (TGFb) that have specific activities as angiogenesis, mitogenesis and activation of macrophages (Camargo et al., 2002). Functions performed by these factors are critical to body functioning, and angiogenesis becomes more important when it comes to surgical wound healing and reduction of post-operative complications, especially tissue ischemia and necrosis (Clifford et al., 2001).

Platelet rich plasma is easy to produce and is inexpensive. However, in the past, its production was more complicated, with high costs (Maia et al., 2009). Lemos et al. (2002), Macedo (2004), Barbosa et al. (2008) developed other protocols to obtain platelet-rich plasma, using laboratory centrifuges to facilitate their production. Currently many researches are carried out using this methodology with good results (Textor et al., 2011; Pazzini et al., 2016b).

According to Camargo et al. (2002), to obtain the platelet-rich plasma is initially done by centrifugation, which can be performed in a single time or in two steps depending on the protocols used. Jameson (2007), Pazzini et al. (2016b) describe a protocol double centrifuging, after the first centrifugation (1600 revolutions per minute (rpm) for 10 minutes), red cells are discarded, then the plasma returns the centrifuge to second centrifugation (2000 revolutions per minute (rpm) for 10 minutes), resulting in the precipitation of platelets and very few erythrocytes in the bottom of the tube. Subsequent to this process, an average of $80 \%$ of the top of the plasma corresponds to the platelet-poor plasma (PPP), which is discarded, and observed the presence of platelet button bottom of the vial, which is resuspended in the remainder of plasma to form the platelet-rich plasma (PRP) (Figure 3).

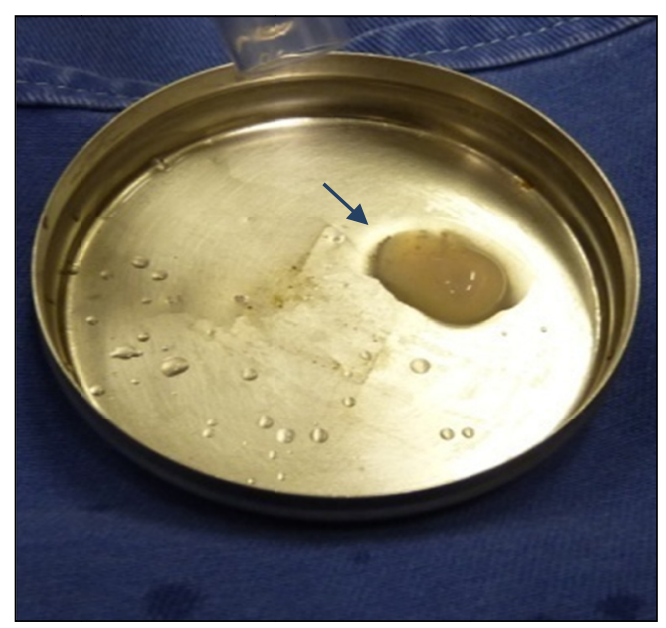

Figure 3. Images of platelet-rich plasma (PRP) procedure at the Veterinary Hospital Faculty of Agricultural and Veterinary Sciences (FCAV) of UNESP, Jaboticabal Campus, 2015

Then, the platelets are activated by the degranulation process and thus releasing growth factors (Albuquerque et al., 2008). Some protocols recommended platelet activation with addition of bovine thrombin, thromboplastin or thrombin autogenous (Bolta, 2007), although others recommend calcium gluconate as a platelet activator (Pazzini et al., 2016b). The use of such substances results in the formation of a gelatinous substance similar to a thrombus called platelet gel (Bolta, 2007).

After its production is carried out the platelet count, it is essential that the count is greater than the whole blood, to occur the proper release of growth factors in the region of its implementation (Pagliosa et al., 2007). The count must provide platelet concentration greater than $1.000 .000 / \mathrm{uL}$, which can be performed on automatic machine in hemocytometer or by indirect counts in blood smears (Lemos et al., 2002).

It is essential that the final product is appropriate; all stages of preparation are carried out with precision, from the collection of blood to obtain the gel in order to avoid the occurrence of inadequate fragmentation of platelets and early release of growth factors in the solution responsible for reducing the effectiveness of the product. Platelet activation should be performed only at the time of application of the product, because after this process the release of growth factors occurs immediately, about 10 minutes, and hour in the first $70 \%$ to $100 \%$ of them have been released. Immediately after release of these factors, the product acquires a gelatinous consistency, 
which provides greater ease for application to the desired site (Albuquerque et al., 2008) Platelet concentrate can also be applied directly on the wound or incision, without being in the form of gel (Jameson, 2007).

Platelet-rich plasma is regarded as an adjuvant product in the healing process of reconstructive surgery because of its auxiliary potential in stimulating processes of new blood vessels (Pazzini et al., 2016a). However, other authors report some contradictory results through the use of the product, and suggest that more experimental studies need to be done in order to really demonstrate efficacy of the product, and also emphasize that more research is needed in veterinary medicine because there are few experimental works related to the use of PRP (Garcia, 2005).

\section{Conclusions}

Researches on platelet-rich plasma used in reconstructive surgery are important because this product has therapeutic characteristics to promote healing. When it's used in skin grafts, platelet-rich plasma is able to improve graft integration in the recipient bed, and reduce necrosis after the surgical procedure. The use of postoperative surgical sponges associated with platelet-rich plasma is indicated to improve the healing of the graft and to avoid its displacement of the recipient bed.

\section{Acknowledgements}

In the Faculty of Agricultural and Veterinary Sciences (FCAV), Universidade Estadual Paulista (UNESP), and the University of Porto by structural and laboratory support; Capes to the scholarship granted in Brazil and Portugal (PDSE), and Cnpq.

\section{Ethics Committee}

This study was approved by the Ethics Committee on Animal Use (CEUA) of the Universidade Estadual Paulista (UNESP), Jaboticabal Campus, protocol number: 11767/14.

\section{References}

Adams, C. D., \& Ramsey, L. M. (2005). Grafts in Dermatologic Surgery: Review and Update on Full and Split Thickness Skin Grafts, Free Cartilage Grafts, and Composite Grafts. Dermatol Surg, 31, 1055-1067. https://doi.org/10.1111/j.1524-4725.2005.31831

Albuquerque, D. P., Oliveira, T. F. M., Maranhão Filho, A. W. A., Milhomens Filho, F., \& Gusmão, E. S. (2008). Aplicação clínico-cirúrgica do plasma rico em plaquetas - Estudo revisional. Odont Clín Cient, 7(2), 119-122.

Amsellem, P. (2011). Complications of reconstructive surgery in companion animals. Vet Clin Small Ani, 41, 995-1006. https://doi.org/10.1016/j.cvsm.2011.05.005

Anitua, E. (2007). Effectiveness of autologus preparation rich in growth factors for the treatment of chronic cutaneous ulcers. https://doi.org/10.1002/jbm.b.30886

Barbosa, A. L. T., Del Carlo, R. J., Gomes, H. C., Oliveira, A. C., Monteiro, B. S., \& Olta, P. R. Z. (2008). Use of platelet growth factors in treating wounds and soft-tissue injuries. Acta Dermat APA, 16(4), 156-165.

Blair, V. P., \& Brown, J. B. (1929). Use and uses of large split skin grafts of intermediate thickness. Surgery Gynecology Obstettrics, 49, 82-97. https://doi.org/10.1201/b17524-2

Bolta, P. R. Z. (2007). Use of platelet growth factors in treating wounds and soft-tissue injuries. Acta Dermat $A P A, 16(4), 156-165$.

Camargo, P. M., Lekovic, V., Weinlaender, M., Vasilic, N., Madzarevic, M., \& Kenney, E. B. (2002). Platelet-rich plasma and bovine porous bone mineral combined with guided tissue regeneration in the treatment of intrabony defects in humans. J Period Res, 37, 300-306. https://doi.org/10.1034/ j.1600-0765.2002.01001

Castro, J. L. C., Huppes, R. R., De Nardi, A. B., \& Pazzini, J. M. (2015). Principios e técnicas de cirurgias reconstrutivas da pele de cães e gatos (atlas colorido) (1st ed., pp. 10-16). Medvep, Curitiba.

Clifford, C. A., Hughes, D., Beal, M. W., Mackin, A. J., Henry, C. J., Shofer, F. S., \& Sorenmo, K. U. (2001). Plasma vascular endothelial growth factor concentrations in healthy dogs and dogs with hemangiosarcoma. $J$ Vet Int Med, 15(2), 131-135. https://doi.org/10.1111/j.1939-1676.2001.tb01244.x

Corr, S. (2009). Intensive, extensive, expansive. managment of distal limb shearing injuries in cats. $J$ Fel Med Surg, 11, 747-57. https://doi.org/10.1016/j.jfms.2009.07.009 
Floryan, K. M., \& Berghoff, W. J. (2004). Intraoperative use of autologous platelet-rich and platelet-poor plasma for orthopedic surgery patients. Aorn J, 80(4), 668-674. https://doi.org/10.1016/S0001-2092(06)61320-3

Fossum, T. W. (2007). Cirurgia de pequenos animais: Cirurgias reconstrutivas (3rd ed., pp. 135-186). São Paulo: Roca.

Fowler, D. (2006). Distal limb and paw injuries. Vet Clin Small Ani, 36, 819-845. https://doi.org/10.1016/j.cvsm.2006.02.004

Garcez, T. N. A., Rosa Paz, A. H., Magrisso, A. B., Mello, H. F., Gonçalves, F. C., Meyer, F. S., ... Cirne-Lima, E. O. (2013). Comparação entre três protocolos de obtenção de plasma rico em plaquetas (prp) utilizando o coelho como modelo experimental. Acta Scien Vet, 41, 1134.

Garcia, R. V. (2005). Utilização de plasma rico em plaquetas (prp) associado a implantes intra-ósseos em mandíbulas de cães. análise histológica. 93f. Tese (Doutorado em Odontologia), Universidade Estadual Paulista, Araraquara.

Hedlund, C. S. (2005). Cirurgia dos sistema tegumentar. In T. W. Fossum (Ed.), Cirurgia de pequenos animais (2nd ed., pp. 135-230). São Paulo: Roca.

Hedlund, C. S. (2008). Cirurgia do sistema tegumentar. In T. W. Fossum (Ed.), Cirurgia de pequenos animais (3rd ed., pp. 224-278). São Paulo: Elsevier.

Jain, N. C. (1993). Examination of the blood and bone marrow. Essentials of veterinary hematology (pp. 1-18). Philadelphia: Lea \& Febiger.

Jameson, C. A. (2007). Autologous platelet concentrate for the production of platelet gel. Ladmedicine, 38(1), 39-42. https://doi.org/10.1309/3ua5hwyvknce01ar

Konig, H. E., \& Liebich, H. G. (2011). Anatomia dos animais domésticos - Textos e atlas colorido (4th ed., pp. 56-58). Porto Alegre: Artmed.

Leffell, D. J. (1996). Split-thickness skin grafts. Atlas of cutaneous surgery (pp. 149-56). Philadelphia: W.B. Saunders C.O.

Lefkovits, J., Plow, E. F., \& Topol, E. J. (1995). Platelet glycoprotein iib/iiia receptors in cardiovascular medicine. New Engl J Med, 332, 1553-1559. https://doi.org/10.1056/NEJM199506083322306

Lemos, J. J., Junior Rossi, R., \& Píspico, R. (2002). Utilização de plasma rico em plaquetas em enxertos ósseos - Proposta de um protocolo de obtenção simplificado. Retrieved from http://www.odontologia.com.br/ artigos.asp?id-225

Macedo, A. P. (2004). Plasma rico em plaquetas: uma análise quantitativa e qualitativa de dois protocolos de obtenção. 63f. Dissertação (Mestrado em Odontologia), Universidade Federal de Santa Catarina, Santa Catarina.

Maia, L., \& Souza, M. V. (2009). Componetes ricos em plaquetas na reparação de afecções tendo-ligamentosas e osteoarticulares em animais. Ciência Rural, 39(4), 1267-1274. https://doi.org/10.1590/S0103-8478200900 5000040

Marx, R. E., Carlson, E. R., Eichstaedt, R. M., Schimmele, S. R., Strauss, J. E., \& Georgeff, K. R. (1998). Platelet-rich plasma: Growth factor enhancement for bone grafts. Oral Surg Oral Med Oral Pathol Oral Radiol Endod, 85(6), 638-46. https://doi.org/10.1016/S1079-2104(98)90029-4

Mota, A. K. R., Lacerda, M. A., Aleixo, G. A., Andrade, L. S. S., \& Coelho, M. C. C. O. (2012). Integração de retalhos de plexo subdérmico para o recobrimento de feridas traumáticas em membros de cães - Avaliação clínica. Medicina Veterinária, 6(2), 1-9.

Pagliosa, G. M., \& Alves, G. E. S. (2007). Considerações sobre a obtenção e o uso do plasma rico em plaquetas e das células mesenquimais indiferenciadas em enxertos ósseos. Ciência Rural, 37(4), 1202-1205. https://doi.org/10.1590/S0103-84782007000400050

Pavletic, M. M. (1999). Atlas of small animal reconstructive surgery (2nd ed., p. 680). Philadelphia, Pennsylvania: W.B. Saunders Company.

Pavletic, M. M. (2007). Tegumento. In D. Slatter (Ed.), Manual de Cirurgia de Pequenos Animais (3rd ed. Vol. 1, pp. 292-321). São Paulo: Manole.

Pavletic, M. M. (2010). Small Animal Wound Magementand Reconstructive Surgery. Free Grafts (3rd ed., Cap. 14, pp. 404-431). Iowa: Wiley-Blackwell. 
Pazzini, J. M., \& Moraes, P. C. (2015). Princípios e técnicas de cirurgias reconstrutivas da pele de cães e gatos (atlas colorido). In J. L. C. Castro, R. R. Huppes, A. B. De Nardi, \& J. M. Pazzini (Eds.), Príncípios e técnicas para realização de enxertos cutâneos (1st ed., Cap. 8, pp. 95-102). Medvep, Curitiba.

Pazzini, J. M., De Nardi, A. B., Huppes, R. R., Gering, A. P., Ferreira, M. G. P. A., Silveira, C. B. P., ... Oliveira, J. A. (2016a). Utilização de plasma rico em plaquetas para estimulação da angiogênese em flape de padrão axial toracordosal em coelhos (Oryctolagus cuniculus). Pesq Vet Bras, 36(2), 108-118. https://doi.org/ $10.1590 / \mathrm{S} 0100-736 \mathrm{X} 2016000200008$

Pazzini, J. M., De Nardi, A. B., Huppes, R. R., Gering, A. P., Ferreira, M. G. P. A., Silveira, C. B. P., ... Santo, R. (2016b). Method to obtain platelet rich plasma from rabbits (Oryctolagus cuniculus). Pesq Vet Bras, 36(1), 39-44. https://doi.org/10.1590/S0100-736X2016000100007

Pope, E. R. (1996). Enxertadura cutânea em malha. In Bojrab (Ed.), Técnicas atuais em cirurgia de pequenos animais (3rd ed., pp. 447-51). São Paulo: Roca.

Ratner, D. (1998). Skin grafting: From here to there. Excision and Repair, 16(1), 75-90. https://doi.org/10.1016/ s0733-8635(05)70488-5

Reece, W. O., \& Swenson, M. J. (2006). Composição e funções do sangue. In W. O. Reece (Ed.), Dukes/Fisiologia dos animais domésticos (12th ed., Cap. 3, pp. 24-48). Rio de Janeiro: Guanabara Koogan.

Richard, A. S. (1999). Bsava manual of canine and feline wound management and reconstruction. Skin graftings (1st ed., Cap. 9, pp. 83-94). England: British.

Santos, L. A. U. (2007). Efeitos da utilização do plasma rico em plaquetas na osteointegração dos enxertos ósseos criopreservados: Estudo histomorfométrico em coelhos. 140f. Dissertação (Mestrado em Ciências), Universidade de São Paulo (USP), São Paulo.

Silva, R. F., Rezende, C. M. F., Paes Leme, F. O., \& Carmona, J. U. (2011). Evaluación del método del tubo para concentrar plaquetas caninas: Estudio celular. Arch Med Vet, 43, 95-98. https://doi.org/10.4067/ S0301-732X2011000100014

Slatter, D. (2007). Manual de cirurgia de pequenos animais: Pele e órgãos anexos (3rd ed., Cap. 22, pp.304-309). São Paulo: Manole.

Swaim, S. F. (2007). Wound healing. In S. S. Swaim (Ed.), Surgery of traumatized skin: Management and reconstruction in the dog and cat (p. 70). Philadelphia: W.B. Saunders.

Textor, J. A., Norris, J. W., \& Tablin, F. (2011). Effects of preparation method, shear force, and exposure to collagen on release of growth factors from equine platelet-rich plasma. Amer $J$ Vet Res, 72(2). https://doi.org/10.2460/ajvr.72.2.271

Tobias, K. M. (2011). Manual de cirurgia de tecidos moles pequenos animais: Enxertos em malha de espessura total (Cap. 5, pp. 44-52). São Paulo: Roca.

Vasconez, L. O., \& Vasconez, H. C. (1994). Plastic \& reconstructive surgery. In L. W. Way (Ed.), Surgical diagnosis and treatment (pp. 1130-1134). Connecticut: Appleton \& Lange Pubs.

Vendramin, F. S., Franco, D., Schamall, R. F., \& Franco, T. R. (2010). Utilização do plasma rico em plaquetas (prp) autólogo em enxertos cutâneos em coelho. Rev Bras Cir Plas, 25(4), 4-10.

William, J., \& Moorms, A. (2013). Enxertos de pele livro. In J. William, \& A. Moorms (Eds.), BSAVA Manual de feridas em cães e gatos (2nd ed., p. 276). Roca.

Zanini, M., Machado Filho, C. A. S., \& Timoner, F. (2004). Uso de esponja cirúrgica para curativo compressivo de enxerto cutâneo. Anais Bras Dermat, 79(3). https://doi.org/10.1590/S0365-05962004000300012

\section{Copyrights}

Copyright for this article is retained by the author(s), with first publication rights granted to the journal.

This is an open-access article distributed under the terms and conditions of the Creative Commons Attribution license (http://creativecommons.org/licenses/by/4.0/). 